https://helda.helsinki.fi

\title{
Ozone and water deficit reduced growth of Aleppo pine seedlings
}

\author{
Le Thiec, D.
}

Elsevier SAS.

2003

Le Thiec, D. and Manninen, S. 2003. Ozone and water deficit reduced growth of Aleppo pine pÿseedlings. Plant Physiology and Biochemistry 41: 5563.

http://hdl.handle.net/1975/232

Downloaded from Helda, University of Helsinki institutional repository.

This is an electronic reprint of the original article.

This reprint may differ from the original in pagination and typographic detail.

Please cite the original version. 


\title{
Ozone and water deficit reduced growth of Aleppo pine seedlings
}

\author{
Didier Le Thiec $^{\mathrm{a}, *}$, Sirkku Manninen ${ }^{\mathrm{b}, 1}$ \\ ${ }^{a}$ Centre de Recherches Forestières, INRA (UMR INRA UHP Ecologie et Ecophysiologie Forestières, Equipe Bioclimatologie), \\ 54280 Champenoux, France \\ ${ }^{b}$ Department of Biology, University of Oulu, PO Box 3000, 90014 Oulu, Finland
}

Received 22 May 2002; accepted 30 July 2002

\begin{abstract}
The effects of ambient and elevated ozone $\left(\mathrm{O}_{3}\right)$ levels on photosynthesis, growth, pigment, biomass and element contents of Aleppo pine (Pinus halepensis Mill.) were studied for two growing seasons $(1997,1998)$. Two-year-old seedlings were exposed to elevated $\mathrm{O}_{3}$ in open-top chambers. The treatments were charcoal-filtered air and non-filtered air $+50 \mathrm{nl} \mathrm{l}^{-1} \mathrm{O}_{3}$ ( $24 \mathrm{~h}$ per day, 7 days per week). In summer 1998, half of the seedlings were drought-stressed (leaf water potential down to approximately $-2 \mathrm{MPa}$ ), while the other half were kept well-watered. At the beginning of the season (1998), current $(c)$ and previous-year $(c+1)$ needles under $\mathrm{O}_{3}$ stress showed an increase in stomatal conductance and net photosynthesis. During the drought period, only stomatal conductance increased in both needle age-classes, whereas the net photosynthesis decreased. At the end of the measuring period, both parameters were reduced in the $\mathrm{O}_{3}$ treatment. Both $\mathrm{O}_{3}$ and drought decreased chlorophyll $a$ and $b$ concentrations, growth and biomass. A carry-over effect of $\mathrm{O}_{3}$ on pigments was also observed. Needle $\mathrm{K}$ content was increased in the $\mathrm{O}_{3}$ treatment. Drought protected Aleppo pine against $\mathrm{O}_{3}$ (less chlorotic mottle and less decrease of stem and branch biomass).
\end{abstract}

(C) 2003 Éditions scientifiques et médicales Elsevier SAS. All rights reserved.

Keywords: Biomass; Critical level; Drought; Ozone; Photosynthesis; Pigments; Pinus halepensis

\section{Introduction}

Among air pollutants, ozone $\left(\mathrm{O}_{3}\right)$ appears to be potentially one of the most harmful in the Mediterranean region, because the meteorological conditions present in this region are particularly favorable to its formation and persistence, and because it is the most ubiquitous. The available evidence strongly suggests that $\mathrm{O}_{3}$ occurs at sufficient concentrations to cause injury to sensitive Mediterranean plant species, including trees [38] Pinus halepensis (Aleppo pine) is a woody species, widespread in the Mediterranean area and useful for reforestation. In most studies, $\mathrm{O}_{3}$ has been demon-

\footnotetext{
Abbreviations: $A$, net carbon dioxide assimilation rate; $\mathrm{AOT} 40, \mathrm{O}_{3}$ exposure over threshold of $40 \mathrm{nl}^{-1}$; C, carbon; $c$, current year; $c+1$, previousyear; $\mathrm{CF}$, charcoal filtered air; $\mathrm{CO}_{2}$, carbon dioxide; car, carotenoid; DS, drought stressed; $g_{\mathrm{w}}$, stomatal conductance to water vapor; $\mathrm{K}$, potassium; $\mathrm{Mn}$, manganese; $\mathrm{NF}+\mathrm{O}_{3}$, non-filtered air + ozone; $\mathrm{O}_{3}$, ozone; OTC, open-top chamber; $\mathrm{P}$, phosphorus; $R / T, \%$ biomass of roots (relative to total plant biomass); WW, well watered.

* Corresponding author.

E-mail address: le_thiec@ @nancy.inra.fr (D. Le Thiec)

${ }^{1}$ Present address: Department of Ecology and Systematics, University of Helsinki, PO Box 44 (Jyrängöntie 2), 00014 Helsinki, Finland.
}

strated to be responsible for the chlorotic mottle and banding observed on the older needles of trees in the field [40] and similar symptoms have been induced on the current year $(c)$ foliage when trees were exposed to sufficiently elevated levels of $\mathrm{O}[15]$ Changes such as reduced stomatal conductance, rates of photosynthesis [1,20] and pigment concentrations [1] have also been reported. However, the discrepancies in some results (such as starch contents) among the different experiments may be related to different $\mathrm{O}_{3}$ exposure designs, as well as different developmental and environmental conditions.

For tropospheric $\mathrm{O}_{3}$, the critical level for vegetation is currently expressed as the accumulated exposure above a threshold concentration of $40 \mathrm{nl} \mathrm{l}^{-1}$ (AOT40). The Level I approach of AOT40 does not consider any factor that may influence a plant's sensitivity to $\mathrm{O}_{2}[14]$ Water shortage is probably the most important factor limiting the growth of the Mediterranean vegetation. Therefore, the interactive effects of $\mathrm{O}_{3}$ and water stress on the physiology of Aleppo pine may have ecological implications. Wellburn and Wellburn [40] also pointed out the detrimental effect of high levels of $\mathrm{O}_{3}$ which affect the ability of the tree to resist water stress. Barnes et al.[4] concluded that future studies should address 
$\mathrm{O}_{3}$ exposure-response relationships in terms of the effective dose of the pollutant absorbed, paying specific attention to possibly important interactions between $\mathrm{O}_{3}$ exposure and other stresses (e.g. drought).

The objective of this study was to investigate the effect of $\mathrm{O}_{3}$, drought and their interaction on growth, biomass production, photosynthesis, pigment and foliar nutrient concentrations of $P$. halepensis in order to discuss the role of drought as a factor modifying the response of trees to $\mathrm{O}_{3}$.

\section{Results}

\subsection{Ozone concentrations}

The ambient $\mathrm{O}_{3}$ levels at the site were relatively high, particularly in August 1997 and May and August 1998 Fig. 1). The maximum daily $(24 \mathrm{~h})$ mean concentrations reached $88 \mathrm{nl} \mathrm{l}^{-1}$ in 1997 and $91 \mathrm{nl} \mathrm{l}^{-1}$ in 1998. The highest hourly $\mathrm{O}_{3}$ concentration was $108 \mathrm{nl} \mathrm{l}^{-1}$ on 12 August 1997 and $106 \mathrm{nl} \mathrm{l}^{-1}$ on 12 May 1998. The AOT40s were calculated for daylight hours $\left(>50 \mathrm{~W} \mathrm{~m}^{-2}\right.$ ) between May and October. At the end of October, the AOT40 for ambient air (on the site) had accumulated to an AOT40 of 24.25/20.78 $\mu \mathrm{l} \mathrm{l}^{-1} \mathrm{~h}$ in $1997 / 1998$ and in the non-filtered air + ozone $\left(\mathrm{NF}+\mathrm{O}_{3}\right)$ open-top chambers (OTCs) to 124.04/117.79 $\mathrm{Il} \mathrm{l}^{-1} \mathrm{~h}$, respectively.
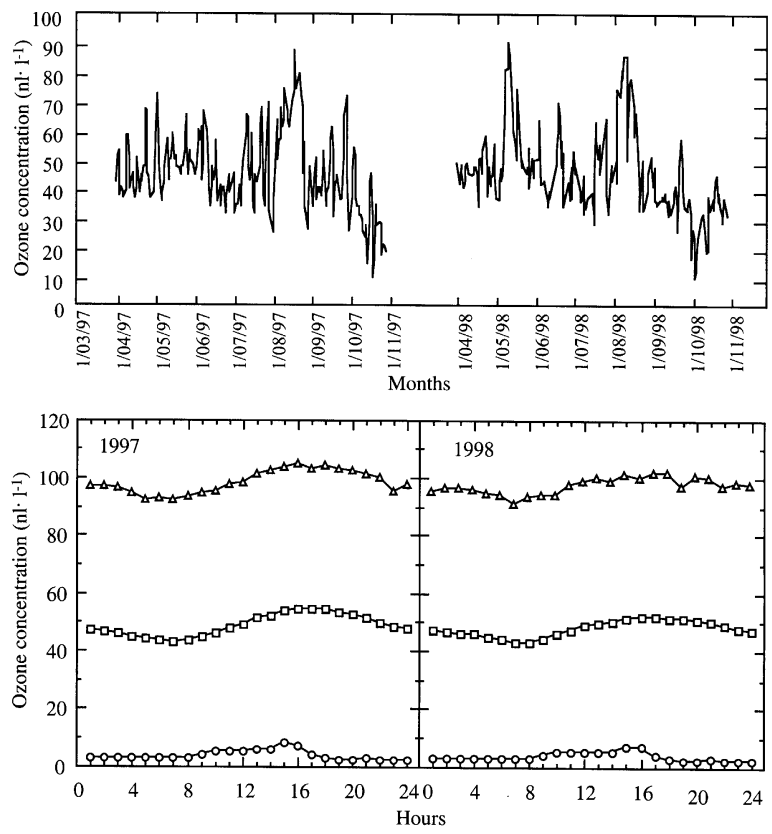

Fig. 1. Daily average $\mathrm{O}_{3}$ concentrations of ambient air during the fumigation experiment, and average day profile of hourly ozone concentrations for the period 1 April-30 September for both years. (O), CF; $(\triangle), \mathrm{NF}+\mathrm{O}_{3}$; $(\square)$, ambient air.

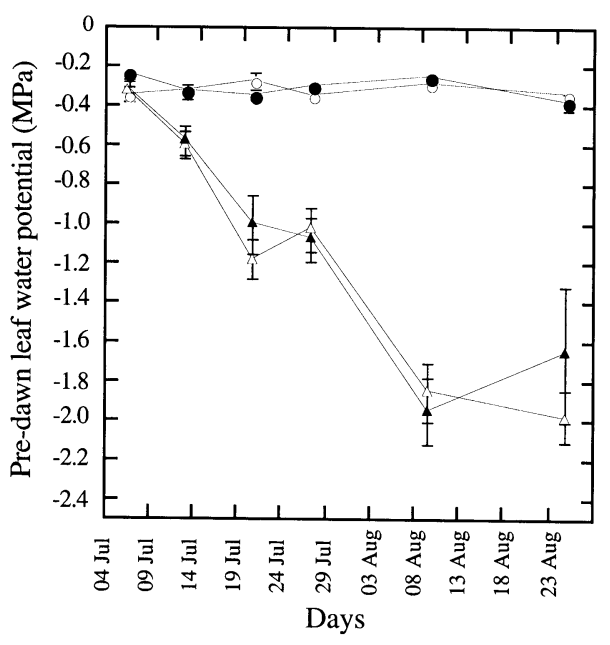

Fig. 2. The change in the pre-dawn leaf water potential during the course of drought period. Error bars indicate S.D. and $n=16$. (O), CF WW; $(\bullet), \mathrm{NF}+$ $\mathrm{O}_{3} \mathrm{WW} ;(\triangle), \mathrm{CF}$ DS; $(\mathbf{\Delta}), \mathrm{NF}+\mathrm{O}_{3}$ DS.

\subsection{Pre-dawn leaf water potential}

The pre-dawn leaf water potential of both the charcoalfiltered air (CF) and $\mathrm{NF}+\mathrm{O}_{3}$ drought-stressed (DS) seedlings had declined to about $-2.0 \mathrm{MPa}$ from 8 July until the end of the drought on 24 August 1998 [Fig. 2). There was no difference between the $\mathrm{CF}$ and $\mathrm{NF}+\mathrm{O}_{3}$ well-watered (WW) seedlings either.

\subsection{Plant growth}

The average height and diameter growth decreased slightly with increasing $\mathrm{O}_{3}$ concentration in 1997, but the differences between the treatments were not statistically significant Table 1). However, the diameter growth decreased due to the $\mathrm{O}_{3}$ exposure in 1998. Drought had a marked $(P<0.001)$ negative effect on the growth. Before drought, there was no difference between WW and future DS trees within the two treatments (data not shown). There was no interaction between $\mathrm{O}_{3}$ and drought in the case of the height and diameter growth.

The negative effect of $\mathrm{O}_{3}$ alone was also seen as a statistically significant decrease in the wood biomass, whereas drought reduced the weight of needles and root biomass too Table 1. Furthermore, there was an interaction between $\mathrm{O}_{3}$ and drought since the reduction in the wood biomass was smaller in the $\mathrm{NF}+\mathrm{O}_{3} \mathrm{DS}$ seedlings than in the $\mathrm{NF}+\mathrm{O}_{3} \mathrm{WW}$ ones in relation to the CF DS and CF WW controls ( -10 vs. $-45 \%$, respectively). Drought reduced growth and biomass more markedly than did $\mathrm{O}_{3}$. There was no difference in the percentage of roots biomass of relative to total plant biomass between the treatments. 
Table 1

The percentage (\%) of relative growth rate of height and diameter at the end of 1997 and 1998 and the average needle, wood and root, total biomass (dry weight in g per plant) and \% biomass of roots (relative to total plant biomass) $(R / T)$ at the final harvest at the end of the experiment on 10 October 1998

\begin{tabular}{|c|c|c|c|c|c|c|c|c|c|}
\hline \multirow[t]{2}{*}{ Treatment } & \multirow[t]{2}{*}{ Height 1997} & \multirow{2}{*}{$\begin{array}{l}\text { Diameter } \\
1997\end{array}$} & \multirow[t]{2}{*}{ Height 1998} & \multirow{2}{*}{$\begin{array}{l}\text { Diameter } \\
1998\end{array}$} & \multicolumn{4}{|l|}{ Biomass } & \multirow[t]{2}{*}{$R / T$} \\
\hline & & & & & Needles & Wood & Root & Total & \\
\hline CF WW & $28.4 \pm 9.6$ & $38.7 \pm 1.0$ & $28.6 \pm 7.5$ & $67.3 \pm 17.8$ & $96.6 \pm 21.5$ & $68.4 \pm 11.6$ & $86.9 \pm 12.5$ & $251.9 \pm 39.2$ & $34.8 \pm 4.0$ \\
\hline $\mathrm{NF}+\mathrm{O}_{3} \mathrm{WW}$ & $23.5 \pm 12.5$ & $32.2 \pm 2.2$ & $28.7 \pm 7.6$ & $55.8 \pm 13.2$ & $70.7 \pm 26.2$ & $37.6 \pm 18.7$ & $63.0 \pm 24.2$ & $171.4 \pm 62.6$ & $37.0 \pm 9.0$ \\
\hline CF DS & l & l & $18.9 \pm 7.8$ & $51.1 \pm 14.2$ & $61.9 \pm 20.4$ & $48.6 \pm 11.2$ & $50.3 \pm 7.3$ & $160.9 \pm 34.3$ & $32.1 \pm 6.0$ \\
\hline $\mathrm{NF}+\mathrm{O}_{3} \mathrm{DS}$ & I & I & $17.5 \pm 5.6$ & $45.4 \pm 15.3$ & $59.1 \pm 12.7$ & $43.7 \pm 8.0$ & $59.2 \pm 21.2$ & $162.1 \pm 32.6$ & $37.5 \pm 6.0$ \\
\hline $\mathrm{O}_{3}$ & $\mathrm{~ns}$ & $\mathrm{~ns}$ & $\mathrm{~ns}$ & $*$ & $\mathrm{~ns}$ & $* * *$ & ns & $* * *$ & $\mathrm{~ns}$ \\
\hline Drought & l & I & $* * *$ & $* * *$ & $* *$ & $\mathrm{~ns}$ & $* *$ & $*$ & ns \\
\hline $\mathrm{O}_{3} \times$ Drought & I & l & $\mathrm{ns}$ & $\mathrm{ns}$ & $\mathrm{ns}$ & $* *$ & $* *$ & $\mathrm{~ns}$ & $\mathrm{~ns}$ \\
\hline df error & 61 & 61 & 56 & 56 & 31 & 31 & 31 & 31 & 31 \\
\hline
\end{tabular}

\subsection{Gas exchange}

Fig. 3 shows the net photosynthesis $(A)$ and stomatal conductance for water vapor $\left(g_{\mathrm{w}}\right)$ of the $c$ and previous-year $(c+1)$ needles before drought (May-June 1998). The $c$ and $c$ +1 needles had significantly higher values of $g_{\mathrm{w}}$ and $A$ in the $\mathrm{NF}+\mathrm{O}_{3}$ treatment compared to the CF treatment. The $c+1$ needles had a higher $g_{\mathrm{w}}$ than the $c$ ones.

During the drought period, when the diurnal variations in $g_{\mathrm{w}}$ and $A$ of the $c$ needles were monitored Fig. 4, differences between the $\mathrm{CF}$ and $\mathrm{NF}+\mathrm{O}_{3}$ treatments were identified in the case of $g_{\mathrm{w}}$ (higher values in the $c$ needles of the $\mathrm{NF}+\mathrm{O}_{3} \mathrm{WW}$ seedlings). Drought provoked a decrease in $g_{\mathrm{w}}$ and $A$ in both treatments, i.e. stomata were almost closed. There was no interaction between $\mathrm{O}_{3}$ and drought stress.

Fig. 5 shows the diurnal variations in gas exchange parameters in the $c+1$ needles. Again, in the case of the WW seedlings, the $\mathrm{NF}+\mathrm{O}_{3}$ seedlings had a higher $g_{\mathrm{w}}$ than the $\mathrm{CF}$ ones. However, this $\mathrm{O}_{3}$-related increase in $g_{\mathrm{w}}$ did not give rise to higher photosynthetic rates. Drought stress had a smaller effect on the $g_{\mathrm{w}}$ of $c+1$ needles compared to the $g_{\mathrm{w}}$ of $c$ needles Fig. 4, i.e. the stomata of $c+1$ needles were not as closed as were the stomata of $c$ needles. The $\mathrm{NF}+\mathrm{O}_{3} \mathrm{DS}$ trees had the lowest $g_{\mathrm{w}}$ and $A$. This suggests that there was an interaction between $\mathrm{O}_{3}$ and drought stress.

After rewatering the DS seedlings, the $c$ needles of both, the $\mathrm{NF}+\mathrm{O}_{3} \mathrm{WW}$ and $\mathrm{NF}+\mathrm{O}_{3} \mathrm{DS}$ seedlings showed a decrease in $g_{\mathrm{w}}$ and $A$ in September 1998 Fig. 6, but the

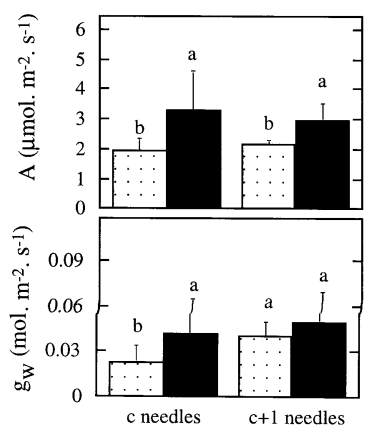

Fig. 3. The net photosynthesis and stomatal conductance for the $c$ and $c+1$ needlec before drought (May-June 1998). Error bars indicate S.D. and $n=$ 12. (घ), $\mathrm{CF} ;(\boldsymbol{\square}), \mathrm{NF}+\mathrm{O}_{3}$. decrease was smaller (not significant) in the $\mathrm{NF}+\mathrm{O}_{3} \mathrm{DS}$ than CF DS seedlings.

\subsection{Pigment concentrations}

$\mathrm{O}_{3}$ fumigation caused chlorotic mottle (data not shown) and decreased pigment concentrations in summer 1998. The chlorophyll $a$ (chl a) and $b(\mathrm{chl} \mathrm{b})$ concentrations and the chl $\mathrm{a}+\mathrm{b} /$ carotenoid (car) ratio in the $c$ and $c+1$ needles as well as the car concentration in the $c+1$ needles of the $\mathrm{NF}+\mathrm{O}_{3}$ seedlings were markedly lower than those in the needles of the CF seedlings in October 1998 Table 2). On the other hand, drought markedly $(P<0.05)$ decreased the chl b and $a$ $+b$ concentrations and chl $a+b /$ car ratio in the $c$ needles of the CF seedlings as well as the chl a concentration and chl $a$ $+b /$ car ratio in the $c+1$ needles of the CF seedlings.

In order to check the health of trees after several months with no $\mathrm{O}_{3}$ fumigation, the pigment concentrations were measured again at the end of May 1999. The new $c$ needles of the $\mathrm{NF}+\mathrm{O}_{3}$ seedlings only had a markedly lower chl a + $\mathrm{b}$ /car ratio compared to those of the $\mathrm{CF}$ seedlings, whereas in the case of the $c+1$ needles both the chl a and b concentra-
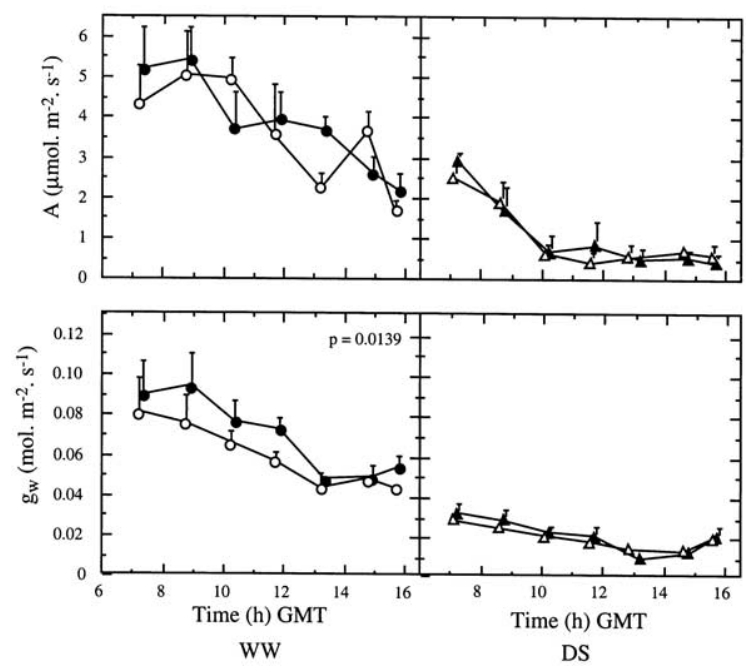

Fig. 4. The diurnal gas exchange response of the $c$ needles during drought period (July-August 1998). Error bars indicate S.D. and $n=8$. (O), CF WW; $(\bullet), \mathrm{NF}+\mathrm{O}_{3} \mathrm{WW} ;(\triangle), \mathrm{CF} \mathrm{DS} ;(\boldsymbol{\Delta}), \mathrm{NF}+\mathrm{O}_{3} \mathrm{DS}$. 


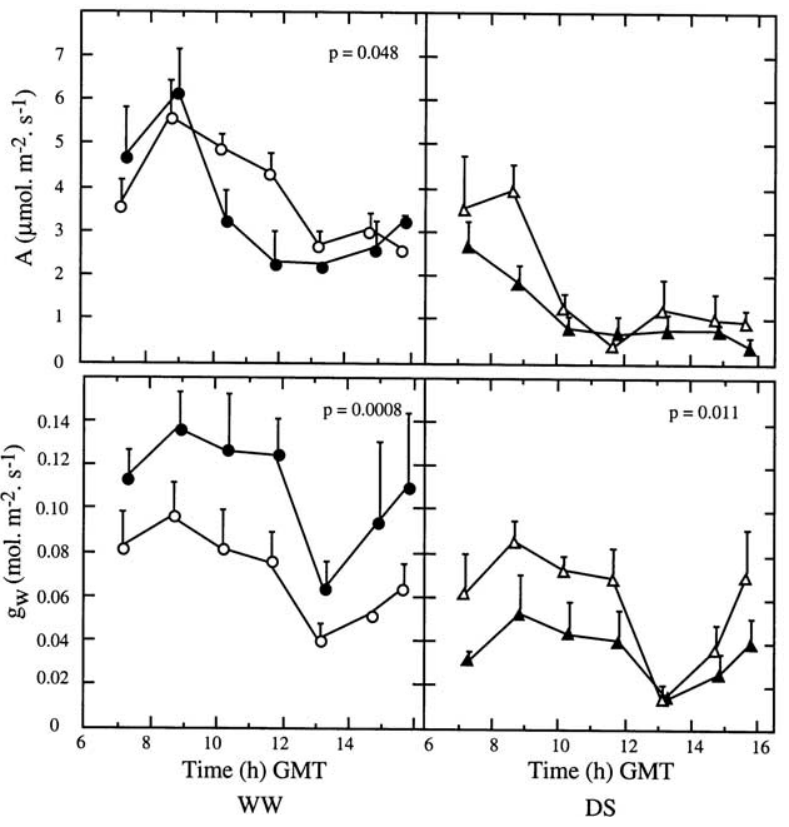

Fig. 5. The diurnal gas exchange response of the $c+1$ needles during drought period (July-August 1998). Error bars indicate S.D. and $n=8$. (O), $\mathrm{CF} W W ;(\bullet), \mathrm{NF}+\mathrm{O}_{3} \mathrm{WW} ;(\triangle), \mathrm{CF} \mathrm{DS} ;(\boldsymbol{\Delta}), \mathrm{NF}+\mathrm{O}_{3} \mathrm{DS}$.

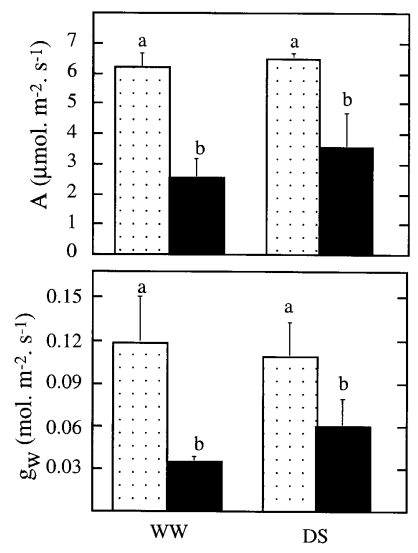

Fig. 6. The net photosynthesis and stomatal conductance for the $c$ needles after rewatering (September 1998). Error bars indicate S.D. and $n=8$. (回), $\mathrm{CF} ;(\square), \mathrm{NF}+\mathrm{O}_{3}$.

tions and the chl a $+\mathrm{b} / \mathrm{car}$ ratio were decreased under elevated $\mathrm{O}_{3}$ Table 2 . The $c+1$ needles of the $\mathrm{NF}+\mathrm{O}_{3}$ DS seedlings had now markedly $(P<0.05)$ higher chl a, chl a + $b$ and car concentrations than those of the $\mathrm{NF}+\mathrm{O}_{3} \mathrm{WW}$ seedlings. There were no differences in the pigment concentrations and ratios between the CFWW and CF DS seedlings.

\subsection{Nutrient contents}

$\mathrm{O}_{3}$ had a significant effect on $\mathrm{C}$ (decrease) and $\mathrm{K}$ (increase) levels of the $c$ needles. Drought stress significantly affected the foliar C (increase), P (decrease), $\mathrm{Mg}$ (increase), $\mathrm{Mn}$ (increase) and $\mathrm{K}$ (decrease) contents Table 3p. The interaction between water stress and $\mathrm{O}_{3}$ was significant on the $\mathrm{C}$ and $\mathrm{K}$ levels, particularly in this latter case for $\mathrm{K}$ content in the $\mathrm{NF}+\mathrm{O}_{3}$ DS seedlings. There were also significant changes in the elemental contents of the $c+1$ needles; there was a significant decrease in the $\mathrm{N}$ content and an increase in the Mn content of the $c+1$ needles with increasing $\mathrm{O}_{3}$ dose. The drought stress provoked a decrease in both the $\mathrm{K}$ and $\mathrm{P}$ content of the $c$ needles of the CF seedlings.

$\mathrm{Ca}, \mathrm{K}$ and $\mathrm{P}$ were found to be most abundant in the epidermis, mesophyll and in the guard cells (data not shown). Both needle age-classes showed increasing concentrations of $\mathrm{Ca}$ in the mesophyll tissue with increasing $\mathrm{O}_{3}$ exposure. Potassium, in turn, had a tendency to decrease in the guard cells of the both needle age-classes and in the mesophyll of the $c+1$ needles.

\section{Discussion}

$\mathrm{O}_{3}$ had no effect on growth (height and diameter) in 1997, and there were no changes in gas exchange and pigments either [26] Thus we did not expect any $\mathrm{O}_{3}$ response in 1998, as the AOT40 was lower than in 1997 and, especially, if we ignore possible cumulative effects of the 1997 exposure. However, some significant changes in gas exchange and pigments were already observed in May 1998 [26] (but no change for growth, data not shown). There are two possible explanations for that, (a) the observed responses were due to peak $\mathrm{O}_{3}$ concentrations Fig. 1 and/or (b) there was a marked carry-over effect.

In the present experiment, with high daily $\mathrm{O}_{3}$ concentration Fig. 1, we found a significant increase in the stomatal conductance of Pinus halepensis before and during the water stress period and a decrease at the end of experiment. In other $\mathrm{O}_{3}$ studies on Pinus halepensis, the authors have found a decrease in the stomatal conductance, except in the case of Fontaine et al. [13], who found the highest values in the one-year old needles (no significant difference). Several hypotheses have been presented to explain such an increase in gw. In general, the increase in stomatal conductance may depend on the fumigation history or on the relative humidity [21] as well as on different leaf types [35] or leaf anatomy and water status of the plant [27] Eamus et al. [11] for example, concluded that this result may be attributed to a decrease in the intercellular $\mathrm{CO}_{2}$ concentration due to enhanced photosynthesis, or it may reflect a long-lasting impairment of stomatal regulation by $\mathrm{O}_{3}$ in Norway spruce. The increase in stomatal conductance may depend on the fumigation history or on the relative humidity [21] as well as on different leaf types [35] or leaf anatomy and water status of the plant [27] The work of Hassan et al. [17] provides another explanation: a direct effect of $\mathrm{O}_{3}$ on the epidermal complex leading to stomatal opening. Furthermore, whole plants may compensate for small losses of leaf tissue or photosynthetic capacity with increased photosynthesis in younger undamaged leaves. For example, Beyers et al. [6] found that the $\mathrm{c}$ needles of $\mathrm{O}_{3}$-exposed ponderosa pine had 
Table 2

Pigment concentrations and ratios of the $c$ and $c+1$ needles in October $1998(n=16)$ and May $1999(n=6-8) . F$ values are given for the effect of $\mathrm{O}_{3}$, water supply and interaction between them

\begin{tabular}{|c|c|c|c|c|c|c|}
\hline & Pigment con & ions $\left(\mathrm{mg} \mathrm{g}^{-1}\right.$ & & & & \\
\hline & Chl a & Chl b & Chl $a+b$ & Car & $\mathrm{Chl} \mathrm{a/b}$ & $\mathrm{Chl} \mathrm{a}+\mathrm{b} / \mathrm{car}$ \\
\hline Oct. 1998 , c ne & & & & & & \\
\hline CF WW & $5.02 \pm 0.91$ & $1.83 \pm 0.41$ & $6.85 \pm 0.73$ & $1.04 \pm 0.13$ & $2.87 \pm 0.63$ & $6.64 \pm 0.41$ \\
\hline CF DS & $4.63 \pm 0.55$ & $1.54 \pm 0.23$ & $6.17 \pm 0.76$ & $1.01 \pm 0.09$ & $3.02 \pm 0.16$ & $6.01 \pm 0.29$ \\
\hline $\mathrm{NF}+\mathrm{O}_{3} \mathrm{WW}$ & $3.97 \pm 1.10$ & $1.52 \pm 0.40$ & $5.49 \pm 1.02$ & $0.94 \pm 0.17$ & $2.77 \pm 0.71$ & $5.89 \pm 0.50$ \\
\hline $\mathrm{NF}+\mathrm{O}_{3} \mathrm{DS}$ & $4.38 \pm 0.72$ & $1.48 \pm 0.26$ & $5.86 \pm 0.97$ & $1.00 \pm 0.12$ & $2.98 \pm 0.12$ & $5.84 \pm 0.36$ \\
\hline $\mathrm{O}_{3}$ & $9.362 * *$ & $5.034 *$ & $14.351 * * *$ & $3.128 \mathrm{~ns}$ & $0.345 \mathrm{~ns}$ & $24.418 * * *$ \\
\hline Drought & $0.001 \mathrm{~ns}$ & $3.824 \mathrm{~ns}$ & $0.505 \mathrm{~ns}$ & $0.413 \mathrm{~ns}$ & $2.077 \mathrm{~ns}$ & $10.100 * *$ \\
\hline $\begin{array}{l}\mathrm{O}_{3} \times \text { Drought } \\
\text { df error }\end{array}$ & $\begin{array}{l}3.646 \mathrm{~ns} \\
60\end{array}$ & $\begin{array}{l}2.160 \mathrm{~ns} \\
60\end{array}$ & $\begin{array}{l}5.715^{*} \\
60\end{array}$ & $\begin{array}{l}1.741 \mathrm{~ns} \\
60\end{array}$ & $\begin{array}{l}0.069 \mathrm{~ns} \\
60\end{array}$ & $\begin{array}{l}6.873^{*} \\
60\end{array}$ \\
\hline Oct. $1998, c+$ & & & & & & \\
\hline CF WW & $5.39 \pm 0.66$ & $1.80 \pm 0.24$ & $7.19 \pm 0.89$ & $1.15 \pm 0.12$ & $3.01 \pm 0.16$ & $6.22 \pm 0.29$ \\
\hline CF DS & $4.93 \pm 0.55$ & $1.68 \pm 0.22$ & $6.61 \pm 0.75$ & $1.13 \pm 0.10$ & $2.95 \pm 0.14$ & $5.83 \pm 0.30$ \\
\hline $\mathrm{NF}+\mathrm{O}_{3} \mathrm{WW}$ & $3.63+0.88$ & $1.28 \pm 0.34$ & $4.90 \pm 0.21$ & $0.91 \pm 0.13$ & $2.88 \pm 0.33$ & $5.31 \pm 0.68$ \\
\hline $\mathrm{NF}+\mathrm{O}_{3} \mathrm{DS}$ & $3.97 \pm 0.69$ & $1.40 \pm 0.36$ & $5.37 \pm 1.00$ & $0.99 \pm 0.12$ & $2.91 \pm 0.35$ & $5.44 \pm 0.63$ \\
\hline $\mathrm{O}_{3}$ & $58.826^{* * *}$ & $28.577 * * *$ & $51.284 * * *$ & $42.554 * * *$ & $1.659 \mathrm{~ns}$ & $25.593 * * *$ \\
\hline Drought & $0.094 \mathrm{~ns}$ & $0.001 \mathrm{~ns}$ & $0.053 \mathrm{~ns}$ & $0.727 \mathrm{~ns}$ & $0.014 \mathrm{~ns}$ & $1.052 \mathrm{~ns}$ \\
\hline $\mathrm{O}_{3} \times$ Drought & $5.094^{*}$ & $2.580 \mathrm{~ns}$ & $4.483^{*}$ & $2.503 \mathrm{~ns}$ & $0.427 \mathrm{~ns}$ & $4.061^{*}$ \\
\hline df error & 59 & 59 & 59 & 59 & 59 & 59 \\
\hline May 1999, c ne & & & & & & \\
\hline CF WW & $4.37 \pm 0.23$ & $1.50 \pm 0.15$ & $5.87 \pm 0.37$ & $0.83 \pm 0.04$ & $2.92 \pm 0.17$ & $7.04 \pm 0.34$ \\
\hline CF DS & $4.63 \pm 0.24$ & $1.53 \pm 0.10$ & $6.16 \pm 0.33$ & $0.86 \pm 0.04$ & $3.02 \pm 0.08$ & $7.17 \pm 0.27$ \\
\hline $\mathrm{NF}+\mathrm{O}_{3} \mathrm{WW}$ & $4.52 \pm 0.55$ & $1.49 \pm 0.32$ & $6.00 \pm 0.86$ & $0.91 \pm 0.09$ & $3.09 \pm 0.32$ & $6.58 \pm 0.49$ \\
\hline $\mathrm{NF}+\mathrm{O}_{3} \mathrm{DS}$ & $4.21 \pm 0.35$ & $1.35 \pm 0.21$ & $5.56 \pm 0.53$ & $0.84 \pm 0.07$ & $3.17 \pm 0.31$ & $6.65 \pm 0.35$ \\
\hline $\mathrm{O}_{3}$ & $0.896 \mathrm{~ns}$ & $1.554 \mathrm{~ns}$ & $1.172 \mathrm{~ns}$ & $1.086 \mathrm{~ns}$ & $3.019 \mathrm{~ns}$ & $12.076^{* * *}$ \\
\hline Drought & $0.018 \mathrm{~ns}$ & $0.474 \mathrm{~ns}$ & $0.119 \mathrm{~ns}$ & $0.954 \mathrm{~ns}$ & $0.979 \mathrm{~ns}$ & $0.546 \mathrm{~ns}$ \\
\hline $\mathrm{O}_{3} \times$ Drought & $4.029 \mathrm{~ns}$ & $1.114 \mathrm{~ns}$ & $2.888 \mathrm{~ns}$ & $4.071 \mathrm{~ns}$ & $0.022 \mathrm{~ns}$ & $0.040 \mathrm{~ns}$ \\
\hline df error & 25 & 25 & 25 & 25 & 25 & 25 \\
\hline May $1999, c+$ & & & & & & \\
\hline CF WW & $5.82 \pm 0.70$ & $2.31 \pm 0.34$ & $8.13 \pm 1.03$ & $1.19 \pm 0.11$ & $2.53 \pm 0.10$ & $6.81 \pm 0.32$ \\
\hline CF DS & $5.81 \pm 0.41$ & $2.41 \pm 0.36$ & $8.22 \pm 0.74$ & $1.19 \pm 0.07$ & $2.44 \pm 0.21$ & $6.88 \pm 0.28$ \\
\hline $\mathrm{NF}+\mathrm{O}_{3} \mathrm{WW}$ & $4.56 \pm 0.97$ & $1.76 \pm 0.51$ & $6.31 \pm 1.46$ & $1.01 \pm 0.16$ & $2.64 \pm 0.25$ & $6.19 \pm 0.70$ \\
\hline $\mathrm{NF}+\mathrm{O}_{3} \mathrm{DS}$ & $5.76 \pm 0.45$ & $2.17 \pm 0.42$ & $7.94 \pm 0.64$ & $1.23 \pm 0.16$ & $2.78 \pm 0.83$ & $6.53 \pm 0.80$ \\
\hline $\mathrm{O}_{3}$ & $6.692 *$ & $6.459^{*}$ & $7.494 *$ & $2.027 \mathrm{~ns}$ & $1.672 \mathrm{~ns}$ & $4.632^{*}$ \\
\hline Drought & $5.632^{*}$ & $2.752 \mathrm{~ns}$ & $5.012 *$ & $4.825^{*}$ & $0.018 \mathrm{~ns}$ & $0.831 \mathrm{~ns}$ \\
\hline $\mathrm{O}_{3} \times$ Drought & $5.683^{*}$ & $1.037 \mathrm{~ns}$ & $3.945 \mathrm{~ns}$ & $4.561^{*}$ & $0.419 \mathrm{~ns}$ & $0.359 \mathrm{~ns}$ \\
\hline df error & 25 & 25 & 25 & 25 & 25 & 25 \\
\hline
\end{tabular}

the highest photosynthetic rates, whereas there was no change in stomatal conductance.

\subsection{The role of stomata}

The needles of Aleppo pine seedlings have sunken stomata and the epistomatal cavity is filled with epicuticular waxes; it is suggested that this morphology represents a water conservation mechanism, creating a greater barrier to water loss than to $\mathrm{CO}_{2}$ entry into the needle interior [2] Long-term $\mathrm{O}_{3}$ exposure has been reported to degrade and erode the waxes [3], and presumably this structural alteration reduces the effectiveness of the wax as a water barrier. This may lead to an apparent increase in the water loss. However, we did not observe any $\mathrm{O}_{3}$-related, enhanced degradation of epicuticular waxes around the stomata or in the substomatal cavity (data not shown). The conflicting evidences suggest that further research will have to be done to explain increased stomatal conductance. Fact is that, in our study, the stomata were first open, but were closed later, and finally the photosynthesis decreased due to more and more severe damage with the increasing absorbed $\mathrm{O}_{3}$ dose [17]

\subsection{The contribution of drought}

In this drought experiment, the $c$ needles of both the $\mathrm{CF}$ $\mathrm{DS}$ and $\mathrm{NF}+\mathrm{O}_{3}$ DS seedlings showed significant reductions in $g_{\mathrm{w}}$ and $A$ (stomata were quite closed). The $g_{\mathrm{w}}$ of $c+1$ needles also decreased, but the stomata seemed to remain more open than in the $c$ needles. The $\mathrm{O}_{3}$ exposure led to a reduction in the $g_{\mathrm{w}}$ of $c+1$ needles in the $\mathrm{NF}+\mathrm{O}_{3} \mathrm{DS}$ seedlings. This suggests that drought protected the seedlings 
Table 3

The total element content ( $\%$ dry weight) of the $c$ and $c+1$ needles sampled on 9 October $1998(\mathrm{df}$ error $=12)$

\begin{tabular}{|c|c|c|c|c|c|c|c|c|}
\hline $\begin{array}{l}\text { Element } \\
\text { Treatment }\end{array}$ & $\mathrm{C}$ & $\mathrm{N}$ & $\mathrm{C} / \mathrm{N}$ & $\mathrm{P}$ & $\mathrm{K}$ & $\mathrm{Ca}$ & $\mathrm{Mg}$ & $\mathrm{Mn}$ \\
\hline \multicolumn{9}{|l|}{$C$} \\
\hline CF WW & $51.75 \pm 0.22$ & $3.42 \pm 0.07$ & $15.11 \pm 0.33$ & $0.31 \pm 0.02$ & $1.29 \pm 0.06$ & $0.18 \pm 0.06$ & $0.098 \pm 0.007$ & $0.016 \pm 0.003$ \\
\hline $\mathrm{NF}+\mathrm{O}_{3} \mathrm{WW}$ & $51.25 \pm 0.07$ & $3.30 \pm 0.23$ & $15.56 \pm 1.32$ & $0.33 \pm 0.03$ & $1.48 \pm 0.04$ & $0.20 \pm 0.08$ & $0.093 \pm 0.005$ & $0.015 \pm 0.004$ \\
\hline CF DS & $51.90 \pm 0.14$ & $3.26 \pm 0.07$ & $15.88 \pm 0.18$ & $0.25 \pm 0.02$ & $1.29 \pm 0.06$ & $0.20 \pm 0.05$ & $0.111 \pm 0.010$ & $0.021 \pm 0.002$ \\
\hline $\mathrm{NF}+\mathrm{O}_{3} \mathrm{DS}$ & $51.85 \pm 0.07$ & $3.25 \pm 0.12$ & $15.97 \pm 0.61$ & $0.26 \pm 0.02$ & $1.25 \pm 0.06$ & $0.24 \pm 0.03$ & $0.104 \pm 0.005$ & $0.022 \pm 0.004$ \\
\hline $\mathrm{O}_{3}$ & $* *$ & ns & ns & ns & $*$ & ns & ns & ns \\
\hline Drought & $* *$ & $\mathrm{~ns}$ & ns & $* * *$ & $* *$ & ns & $*$ & $* *$ \\
\hline $\begin{array}{l}\mathrm{O}_{3} \times \text { Drought } \\
c+1\end{array}$ & $*$ & $\mathrm{~ns}$ & ns & ns & $* *$ & $\mathrm{~ns}$ & ns & ns \\
\hline CF WW & $52.65 \pm 0.13$ & $3.29 \pm 0.10$ & $16.01 \pm 0.45$ & $0.20 \pm 0.06$ & $0.69 \pm 0.23$ & $0.28 \pm 0.11$ & $0.096 \pm 0.009$ & $0.018 \pm 0.005$ \\
\hline $\mathrm{NF}+\mathrm{O}_{3} \mathrm{WW}$ & $52.40 \pm 0.16$ & $3.05 \pm 0.18$ & $17.22 \pm 1.01$ & $0.26 \pm 0.02$ & $0.84 \pm 0.02$ & $0.33 \pm 0.03$ & $0.090 \pm 0.007$ & $0.023 \pm 0.004$ \\
\hline CF DS & $52.09 \pm 0.16$ & $3.13 \pm 0.07$ & $16.60 \pm 0.32$ & $0.23 \pm 0.03$ & $1.02 \pm 0.10$ & $0.32 \pm 0.10$ & $0.093 \pm 0.013$ & $0.021 \pm 0.003$ \\
\hline $\mathrm{NF}+\mathrm{O}_{3} \mathrm{DS}$ & $52.54 \pm 0.19$ & $3.00 \pm 0.15$ & $17.54 \pm 0.88$ & $0.21 \pm 0.02$ & $0.85 \pm 0.07$ & $0.30 \pm 0.03$ & $0.091 \pm 0.009$ & $0.022 \pm 0.002$ \\
\hline $\mathrm{O}_{3}$ & $\mathrm{~ns}$ & $*$ & ns & ns & $\mathrm{ns}$ & $\mathrm{ns}$ & ns & $*$ \\
\hline Drought & $*$ & ns & ns & ns & $*$ & ns & ns & ns \\
\hline $\mathrm{O}_{3} \times$ Drought & $* *$ & ns & ns & ns & $*$ & ns & ns & ns \\
\hline
\end{tabular}

against the $\mathrm{O}_{3}$ impact. After rewatering Fig. 6, we also observed that the $\mathrm{NF}+\mathrm{O}_{3}$ DS seedlings had higher values of $g_{\mathrm{w}}$ and $A$ than the $\mathrm{NF}+\mathrm{O}_{3} \mathrm{WW}$ seedlings. Tingey and Hogsett [37] clearly indicated that water stress can protect plants from $\mathrm{O}_{3}$ injury mainly through its influence on stomatal conductance, rather than through biochemical mechanisms. The chlorophyll results provide further evidence for the effect of water stress that may be seen as beneficial in this context (see below).

The changes in the gas exchange parameters caused by drought explain the decrease in the height and diameter growth and also in the biomass of needles and woody parts. The reductions in the biomass of different plant parts were proportional to each other, and therefore, the $R / T$ ratio did not change. $\mathrm{O}_{3}$ also provoked a decrease in the above-ground and below-ground biomass of the WW seedlings; these results are in contrast with those of Wellburn and Wellburn [40] The decrease in the photosynthetic rate at the end of the experiment could not alone explain the significant decrease in the biomass. Possible factors further decreasing biomass accumulation could be enhancing respiration as suggested by Dizengremel and Gérant [10]] or increase root exudation. Also, photosynthetic measurements were taken in the morning between 08:00 and 10:00 h; i.e. during the period of highest daily net $\mathrm{CO}_{2}$ uptake Figs. 4 and 5. This photosynthetic behavior is typical of arid-growth conifers, such as ponderosa pine in the mountains of southern California, USA or as showed for Aleppo pine by Inclán et al. [20]. Both $c$ and $c+1$ needles have equal photosynthetic rates; however, while $A$ in the $c$ needles of the $\mathrm{CF}$ and $\mathrm{NF}+\mathrm{O}_{3}$ seedlings decline similarly during the day, $A$ in the $c+1$ needles of the $\mathrm{NF}+\mathrm{O}_{3}$ seedlings is lower than in the $\mathrm{CF}$ seedlings during the majority of the day (Fig. 5). If the daily pattern of $A$ in the $c+1$ needles of the $\mathrm{CF}$ and $\mathrm{NF}+\mathrm{O}_{3}$ seedlings continued throughout the growing season, then this could explain a decline in biomass.
Foliar chlorophyll content has been found to have a high correlation with the amount of $\mathrm{O}_{3}$-induced chlorotic mottle [30] In the present study, the pigments were chosen as indicators of possible $\mathrm{O}_{3}$-induced needle damage as for occurrence of chlorotic mottle, only the sensitive individuals in a population (of a detector bioindicator) will respond to $\mathrm{O}_{3}$ and (only when they experience) appropriate edaphic and tropospheric conditions coupled with $\mathrm{O}_{3}$ exposures and concentrations sufficient to cause foliar injury. The results show that both treatments, $\mathrm{O}_{3}$ and drought, decreased the needle pigment concentrations and the chl $\mathrm{a}+\mathrm{b} / \mathrm{car}$ ratio. The higher pigment concentrations in the DS than WW NF $+\mathrm{O}_{3}$ seedlings suggest that drought stress decreased $\mathrm{O}_{3}$ flux into the needles [20] In mature Aleppo pines under field conditions, longer needles (i.e. needles developed during years of abundant rain fall) have been found to be associated with higher occurrence of chlorotic mottle [33]

\subsection{Cumulative and carry-over $\mathrm{O}_{3}$ effects on the pigments}

Robinson and Wellburn [31] report a decrease in the chl $\mathrm{a} / \mathrm{b}$ ratio of Norway spruce needles under $\mathrm{O}_{3}$ stress. Such a change was not observed in the present study, as chl b concentrations were also reduced by $\mathrm{O}_{3}$. Indeed, marked changes in the chl $b$ concentration may be expected especially in the needles showing visible $\mathrm{O}_{3}$ damage, as chl b is broken down in senescence [36] and $\mathrm{O}_{3}$ injury seems to be among the factors affecting needle retention in mature Aleppo pines in the field [33] The differences in the chl a, chl $\mathrm{a}+\mathrm{b}$ and car concentrations in the $c+1$ needles between the WW and DS NF $+\mathrm{O}_{3}$ seedlings in May 1999 also suggest that the WW NF $+\mathrm{O}_{3}$ seedlings had not (yet) been able to compensate for the $\mathrm{O}_{3}$-induced chlorophyll loss [31] The lower chl $\mathrm{a}+\mathrm{b}$ /car ratio in the $c$ needles of the $\mathrm{NF}+\mathrm{O}_{3}$ seedlings compared to that in the $c$ needles of the CF seedlings points to a carry-over effect [23] 


\subsection{Changes in the nutrient contents}

The role of nutrition in the $\mathrm{O}_{3}$ sensitivity of woody plants is still under debate [29] Response of nutrient uptake and distribution within different tissues to $\mathrm{O}_{3}$ exposure has been found to be variable depending on species and environmental conditions. In Norway spruce, Keller and Matyssek [22] reported increased concentrations of $\mathrm{Ca}, \mathrm{Mg}$ and $\mathrm{N}$. Le Thiec et al.[24] found increased concentrations of $\mathrm{K}$ and $\mathrm{Ca}$ in the same species, but a decrease in the $\mathrm{K}$ content of the beech leaves after $\mathrm{O}_{3}$ fumigation. On the other hand, Samuelson et al. [32] found that $\mathrm{O}_{3}$ exposure reduced foliar $\mathrm{N}$ concentrations and Fangmeier et al. [12] did not detect any $\mathrm{O}_{3}$ effect on the nutrient content in spring wheat.

In our experiment, $\mathrm{O}_{3}$ reduced the $\mathrm{N}$ content, especially of the $c+1$ needles, which may have contributed to the decrease of pigment concentrations and, consequently, to photosynthesis, growth and biomass production. The needle $\mathrm{K}$ content also changed significantly and this change could result from a perturbation of the mineral nutrition at the root level. According to Barnes and Pfirrmann [5], the increase in the $\mathrm{K}$ levels could be explained by an increasing ion uptake at root level, but our microanalyses revealed a decrease in the $\mathrm{K}$ levels (at the end of experiment), especially in the guard cells. We explain this phenomenon by the fact that $\mathrm{O}_{3}$ exposure may lead to changes in the cell membrane permeability [8] which could cause perturbation in the nutrient compartmentalization [18] The increase in the Ca content of the mesophyll tissue may also be due to this leakage of membrane [9] or due to an involvement of $\mathrm{Ca}$ in detoxification [28] Thus it may be linked to early events under $\mathrm{O}_{3}$ attack. Drought tended to decrease the $\mathrm{P}$ concentrations. This suggests that drought has, by reducing the water supply, also reduced the nutrient supply to the plant, or changed the availability of the ions from the soil solution [16]

The cumulative effects of high $\mathrm{O}_{3}$ concentrations on Aleppo pine seedlings were seen as lower net photosynthesis in the $c$ needles. This may be due to chloroplast damage, which was observed as decreased chl a $+\mathrm{b}$ concentration in both the $c$ and $c+1$ needles. Consequently, growth and biomass were reduced (total biomass was reduced by $32 \%$ for an AOT40 of about $120 \mu 11^{-1} \mathrm{~h}$, consequently we could have $-10 \%$ for a value of $37.5 \mu 1^{-1} \mathrm{~h}$ ). Our study also suggests that drought stress reduced the $\mathrm{O}_{3}$ flux into the needles by reducing stomatal conductance. At any rate, drought reduced the growth and biomass more markedly than $\operatorname{did} \mathrm{O}_{3}$ (except for wood).

\section{Methods}

\subsection{Experimental site, plant material and treatments}

The experiment was performed in an OTC facility at $\mathrm{Col}$ du Donon $\left(48^{\circ} 29^{\prime} \mathrm{N}, 7^{\circ} 05^{\prime} \mathrm{E}\right)$ in France; the site is at $727 \mathrm{~m}$ altitude. A total of four chambers were used, each with a diameter of $3 \mathrm{~m}$ and a height of $2.8 \mathrm{~m}$. On 22 April 1997, 2-year-old seedlings of $P$. halepensis Mill. (provenance Languedoc) were potted in 221 pots filled with $50 \%$ peat, $30 \%$ sand and $20 \%$ perlite, i.e. 16 plants per chamber. A slow-release fertilizer (Nutricot 100, 13/13/13 N/P/K) was mixed with the substrate upon planting. The nutrient additions were the same for each pot and for both years in April. From 25 April 1997, seedlings were exposed to two treatments: $\mathrm{CF}$ and non-filtered air $+50 \mathrm{nl} \mathrm{l}^{-1}(\mathrm{ppb}) \mathrm{O}_{3}\left(\mathrm{NF}+\mathrm{O}_{3}\right)$ (24 h per day, 7 days per week) until 17 October 1997. Treatments were replicated in two OTCs each. The fumigations were continued from 6 May 1998, when the $\mathrm{NF}+\mathrm{O}_{3}$ seedlings were exposed to ambient air $+50 \mathrm{nl} \mathrm{l}^{-1} \mathrm{O}_{3}$ until 9 October 1998. An electric discharge generator (Trailigaz Labo 76, France) supplied with pure oxygen produced $\mathrm{O}_{3} \cdot \mathrm{O}_{3}$ was distributed to the chambers through Teflon tubes under constant flow conditions. Using an UV analyzer (Environment S.A., 1003RS, Poissy, France), air from each chamber and ambient air was continuously pulled through a manifold system and recorded for two 5 min periods every hour. Photosynthetically active radiation (PAR), air temperature and relative air humidity (RH) were also recorded. All data were stored by an automated data acquisition system. Trees were irrigated to field capacity at two days intervals by weighing individual pots. Seedlings were grown in a greenhouse during the winter and brought back to the experimental field at the end of April. Half of the seedlings were exposed randomly to drought stress (no watering) from 8 July to 24 August 1998. On 24 July and 12 August, DS trees were irrigated with an amount of water equivalent to $50 \%$ of their evapotranspiration (pots were weighted in order to determine water loss). At the end of drought period, all the DS trees were irrigated as the WW trees. On 10 October 1998, half of the seedlings were harvested and the rest were moved into a greenhouse for winter in order to avoid strong frost because the experimental site was not a natural habitat for Aleppo pine.

\subsection{Pre-dawn leaf water potential}

At regular periods throughout the drought treatment, the pre-dawn leaf water potential was measured using a Skye pressure chamber [34] Measurements were made between 04:00 and 06:00 hours local time. The pre-dawn water potential was measured on the stem of $c$ shoots.

\subsection{Plant growth}

The height and the basal diameter of all the seedlings were recorded weekly during both years. This measurement was made on two axes at $90^{\circ}$ to each other (circular) to reduce errors resulting from the trunk cross sections not being exactly round. The mean diameter was then calculated. At the end of fumigation the percentage of relative growth rate was calculated for height and diameter and the seedlings were separated into roots (fine roots with coarse roots), stem and 
branch wood and needles. The biomass was determined after drying the material for $96 \mathrm{~h}$ at $65^{\circ} \mathrm{C}$.

\subsection{Leaf gas exchange}

The net $\mathrm{CO}_{2}$ assimilation rate, $A\left(\mu \mathrm{mol} \mathrm{m}{ }^{-2} \mathrm{~s}^{-1}\right)$ and leaf conductance to water vapor, $g_{\mathrm{w}}\left(\mathrm{mol} \mathrm{m} \mathrm{m}^{-2} \mathrm{~s}^{-1}\right)$ were measured using the LiCor model 6200 (USA) portable photosynthesis chamber $(41)$. During the period of shoot extension (but needles had finished to elongate), when measurements were made on the $c$ needles, they were harvested. After this period of shoot extension, one shoot was monitored for the rest of the season, as no subsequent surface area changes occurred. Measurements were carried out between 08:00 and 10:00 GMT inside the OTC and the results were expressed per foliage total surface area. As Aleppo pine needles cannot be approximated to two-dimensional forms, a equation describing their surface area has been developed [26] There were no significant differences in the PAR, vapor pressure deficit, RH and temperature among the treatments during the measurements, these parameters were almost constant. Measurements were made on 12 trees, every time in the same order, per treatment on $c$ and $c+1$ needles. They were carried out on eight separate days from May to June 1998 before the drought stress period. On two occasions the measurements were continued at hourly intervals to follow diurnal variations of the measured parameters during drought. After rewatering, measurements were made on the $c$ needles on two occasions in the morning in September 1998 on all trees. We calculated the average for each tree across the different measurement periods and presented the means of trees.

\subsection{Determination of pigments}

Current-year $(c)$ and $c+1$ juvenile needles were sampled for pigment analyses in mid October 1998 and at the end of May 1999. The needles were frozen with liquid nitrogen and put into a freezer $\left(-70^{\circ} \mathrm{C}\right)$ prior to analysis. The pigments were extracted with dimethyl sulfoxide (DMSO) at $65^{\circ} \mathrm{C}$ for $6 \mathrm{~h}$ according to Hiscox and Israelstam [19] Absorbances were measured at 470, 646 and $663 \mathrm{~nm}$ with a Beckman $\mathrm{DU}^{\circledR}-64$ spectrophotometer. The concentrations of chl a, chl $\mathrm{b}$ and total car were calculated according to Wellburn [39]

\subsection{Nutrient contents}

The needles for microanalysis were sampled between 10:00 and 11:00 GMT on 9 October 1998. Five $c$ and five $c+$ 1 needles were sampled from each seedling, and each needle was analyzed five times. The material to be analyzed was prepared according to the method used in Le Thiec et al. [25]. Sections of plant material were examined under a scanning electron microscope (Stereoscan 90B, Cambridge) at $15 \mathrm{kV}$, equipped with a energy dispersive microanalysis system (EDX, diode Si-Li; Analyzer AN10000 10/25). It was confirmed that the beam of primary electrons did not penetrate other cells by analyzing one layer of cells on a sheet of aluminium. All measurements were made using an X-ray take-off angle of $45^{\circ}$, a measuring time of $100 \mathrm{~s}$, a magnification of 6000 for all examined tissues (stomata, epidermis, mesophyll). In order to convert the microanalysis data into real concentrations (\% dry mass), powdered spruce needles were used as standards (CRM 100 given by Community Bureau of Reference of the Commission of the European Communities). For the chemical analyses, Aleppo pine needles were sampled on 9 October 1998. The samples were dried at $65^{\circ} \mathrm{C}$. Total $\mathrm{P}$ and the cations $(\mathrm{Mg}, \mathrm{K}, \mathrm{Ca}, \mathrm{Mn})$ were mineralized $\left(\mathrm{H}_{2} \mathrm{O}_{2}\right.$ and $\left.\mathrm{HClO}_{4}\right)$ and measured by ICP (Jobin Yvon JY438 Plus). The total $\mathrm{N}$ content was determined using the Kjeldahl method and a Technicon II Autoanalyser, total C by the Anstett method [7]

\subsection{Statistical analysis}

The statistical analysis of the data was performed by the analysis of variance (ANOVA) with the GLM procedure of Statistical Analysis System. Test of equality of averages using Bonferroni ( $t$-test) was applied equally (the same letters indicate that averages are not significantly different, and the alphabetic order corresponds to decreasing values). Significance was as follows: ns, not significant; *, significant $(P$ $<0.05)$; **, highly significant $(P<0.01)$; ***, extremely significant $(P<0.001)$. Since there were only two OTCs (replicates) per treatment, subreplicates (trees) were used rather than real replicates (chambers), in the statistical analysis. All trees from two chambers belonging to the same treatment were pooled, giving four subreplicates. For diurnal gas exchange data, a pair-wise comparison was used.

The effects of time (day of measurement), treatment, OTC were tested using a three-way ANOVA. No significant effects were found due to time or OTC within treatments. This test demonstrated that the experimental conditions were homogenous between different OTC across the time.

\section{Acknowledgements}

This study has been financed by INRA and Academy of Finland. We thank M. Gilles Nourrisson, Christophe Rose and Jean Pierre Garrec for their work during the experiment, François Willm for his help on using the LiCor photosynthesis systems, Dr Oliver Brendel for English language correction.

\section{References}

[1] R. Alonso, S. Elvira, F.J. Castillo, B.S. Gimeno, Interactive effects of ozone and drought stress on pigments and activities of antioxidative enzymes in Pinus halepensis, Plant Cell Environ 24 (2001) 905-916. 
[2] J.L. Araus, A. Febrero, P. Vendrell, Epidermal conductance in different parts of durum wheat grown under Mediterranean conditions: the role of epicuticular waxes and stomata, Plant Cell Environ 14 (1991) $545-558$.

[3] J.D. Barnes, A.W. Davison, T.A. Booth, Ozone accelerates structural degradation of epicuticular wax on Norway spruce needles, New Phytol 110 (1988) 309-318.

[4] J.D. Barnes, B. Gimeno, A. Davison, P. Dizengremel, D. Gérant, F. Bussotti, D. Vellissariou, Air pollution impacts on pine forests in the Mediterranean Basin, in: G. Ne'eman, L. Trabaud (Eds.), Ecology, Biogeography and Management of Pinus halepensis and P. brutia Forest Ecosystems in the Mediterranean Basin, Backhuys Publishers, Leiden, The Netherlands, 2000, pp. 391-404.

[5] J.D. Barnes, T. Pfirrmann, The influence of $\mathrm{CO}_{2}$ and $\mathrm{O}_{3}$, singly and in combination, on gas exchange, growth and nutrient status of radish (Raphanus sativus L, New Phytol 121 (1992) 403-412.

[6] J.L. Beyers, G.H. Riechers, P.J. Temple, Effects of long-term ozone exposure and drought on the photosynthetic capacity of ponderosa pine (Pinus ponderosa Laws.), New Phytol 122 (1992) 81-90.

[7] A. Clément, Point 77 sur certaines analyses foliaires, Internal Publication (1977) 25.

[8] B.I. Chevone, J.R. Seiler, J. Melkonian, R.G. Amundson, Ozonewater stress interactions, in: R.G. Alscher, J.R. Cumming (Eds.), Stress Responses in Plants: Adaptation and Acclimation Mechanisms, Wiley-Liss, Inc, 1990, pp. 311-328.

[9] P. Dizengremel, Effects of ozone on the carbon metabolism of forest trees, Plant Physiol. Biochem 39 (2001) 729-742.

[10] P. Dizengremel, D. Gérant, Interactions between ozone, climatic and nutritional factors on coniferous tree physiology, Final Scientific Report, Synthesis Report, Contract EV 5V CT 93 0263, 1997.

[11] D. Eamus, J.D. Barnes, L. Mortensen, H. Ro-Poulsen, A.W. Davison, Persistent stimulation of $\mathrm{CO}_{2}$ assimilation and stomatal conductance by summer ozone fumigation in Norway spruce, Environ. Pollut 63 (1990) 365-379.

[12] A. Fangmeier, U. Grüters, P. Högy, B. Vermehren, H.J. Jäger, Effects of elevated $\mathrm{CO}_{2}$, nitrogen supply and tropospheric ozone on spring wheat-II. Nutrients (N, P, K, S, Ca, Mg, Fe, Mn, Zn), Environ. Pollut. 96 (1997) 43-59.

[13] V. Fontaine, J. Pelloux, M. Podor, D. Afif, D. Gérant, P. Grieu, P. Dizengremel, Carbon fixation in Pinus halepensis submitted to ozone. Opposite response of ribulose-1,5-bisphosphate carboxylase/oxygenase and phosphoenolpyruvate carboxylase, Physiol. Plant 105 (1999) 187-192.

[14] J. Fuhrer, B. Achermann, Critical Levels for Ozone-Level II. Environmental Documentation No. 115, Swiss Agency for Environment, Forest and Landscape, Bern, Switzerland, 1999.

[15] D. Gérant, M. Podor, P. Grieu, D. Afif, S. Cornu, D. Morabito, J. Banvoy, C. Robin, P. Dizengremel, Carbon metabolism enzyme activities and carbon partitioning in Pinus halepensis Mill. exposed to mild drought and ozone, J. Plant Physiol 148 (1996) 142-147.

[16] T. Gollan, U. Schurr, E.D. Schulze, Stomatal response to drying soil in relation to changes in the xylem sap composition of Helianthus аппииs. I. The concentration of cations, anions, amino acids in, and pH of, the xylem sap, Plant Cell Environ 15 (1992) 551-559.

[17] I.A. Hassan, M.R. Ashmore, J.N.B. Bell, Effects of $\mathrm{O}_{3}$ on the stomatal behaviour of Egyptian varieties of radish (Raphanus sativus $\mathrm{L} . \mathrm{cv}$. Baladey) and turnip (Brassica rapa L. cv. Sultani), New Phytol. 128 (1994) 243-249.

[18] R.L. Heath, F.J. Castillo, Membrane disturbance in response to air pollutants, in: S. Schulte-Hostede, N.M. Darrall, L.W. Blank, A.R. Wellburn (Eds.), Air Pollution and Plant Metabolism, Elsevier, London, UK, 1988, pp. 530-575.

[19] J.D. Hiscox, G.F. Israelstam, A method for the extraction of chlorophyll from leaf tissue without maceration, Can. J. Bot 57 (1979) $1332-1334$.
[20] R. Inclán, R. Alonso, M. Pujadas, J. Terés, B.S. Gimeno, Ozone and drought stress: interactive effects on gas exchange in Aleppo pine (Pinus halepensis Mill.), Chemosphere 36 (1998) 685-690.

[21] K.F. Jensen, B.R. Roberts, Changes in yellow poplar stomatal resistance with $\mathrm{SO}_{2}$ and $\mathrm{O}_{3}$ fumigation, Environ. Pollut 41 (1986) 235-245.

[22] T. Keller, R. Matyssek, Limited compensation of ozone stress by potassium in Norway spruce, Environ. Pollut 67 (1990) 1-14.

[23] C. Langebartels, D. Ernst, W. Heller, C. Lütz, H.D. Payer, H. Sandermann, Ozone responses of trees: results from controlled chamber exposures at the GSF phytotron, in: H. Sandermann, A.R. Wellburn, R.L. Heath (Eds.), Forest Decline and Ozone, 127, Springer. Ecol. Stud, Berlin, Germany, 1997, pp. 163-200.

[24] D. Le Thiec, M. Dixon, J.P. Garrec, Seasonal and annual variations of phosphorus, calcium, potassium and manganese contents in different cross-sections of Picea abies (L.) Karst. needles and Quercus rubra (L.) leaves exposed to elevated $\mathrm{CO}_{2}$, Trees 10 (1995) 55-62.

[25] D. Le Thiec, C. Rose, J.P. Garrec, D. Laffray, P. Louguet, S. Galaup, P. Loosveldt, Alteration of element contents in guard cells of Norway spruce (Picea abies) subjected to ozone fumigation and (or) water stress: X-ray microanalysis study, Can. J. Bot 72 (1994) 86-92.

[26] S. Manninen, D. Le Thiec, C. Rose, G. Nourrisson, F. Radnai, J.P. Garrec, S. Huttunen, Pigment concentrations and ratios of Aleppo pine seedlings exposed to ozone, Water Air Soil Pollut 116 (1999) 333-338.

[27] T.A. Mansfield, Stomata and plant water relations: does air pollution create problems?, Environ. Pollut 101 (1998) 1-11.

[28] H. Marschner, Mineral Nutrition of Higher Plants, Academic Press, London, 1995.

[29] S. Maurer, R. Matyssek, Nutrition and the ozone sensitivity of birch (Betula pendula, II. Carbon balance, water-use efficiency and nutritional status of the whole plant, Trees 12 (1997) 11-20.

[30] P.R. Miller, J.R. Parmeter, O.C. Taylor, E.A. Cardiff, Ozone injury to the foliage of Pinus ponderosa, Phytopathology 53 (1963) 1072-1076.

[31] D.C. Robinson, A.R. Wellburn, Seasonal changes in the pigments of Norway spruce, Picea abies (L.) Karst., and the influence of summer ozone exposure, New Phytol. 119 (1991) 251-259.

[32] L.J. Samuelson, J.M. Kelly, P.A. Mays, G.S. Edwards, Growth and nutrition of Quercus rubra L. seedlings and mature trees after three seasons of ozone exposure, Environ. Pollut 91 (1996) 317-323.

[33] M.J. Sanz, V. Calatayud, E. Calvo, Spatial pattern of ozone injury to Aleppo pine related to air pollution dynamics in a coastal-mountain region of eastern Spain, Environ. Pollut 108 (2000) 239-247.

[34] P.F. Scholander, H.T. Hammel, E.D. Bradstreet, E.A. Hemmingsen, Sap measure in plants, Science 148 (1965) 339-346.

[35] G. Taylor, M.C. Dobson, Photosynthetic characteristics, stomatal responses and water relations of Fagus sylvatica: impact of air quality at a site in southern Britain, New Phytol 113 (1989) 265-273.

[36] H. Thomas, Chlorophyll: a symptom and a regulator of plastid development, New Phytol 136 (1997) 163-181.

[37] D.T. Tingey, W.E. Hogsett, Water stress reduces ozone injury via stomatal mechanism, Plant Physiol 77 (1985) 944-947.

[38] D. Vellissariou, B.S. Gimeno, M. Badiani, I. Fumigalli, A.W. Davison, Records of ozone visible injury in the ECE Mediterranean region, in: L. Kärenlampi, L. Skärby (Eds.), Critical Levels for Ozone in Europe: Testing and Finalizing the ConceptsUNECE Workshop Report Department of Ecology and Environmental, University of Kuopio, Finland, 1996, pp. 343-354.

[39] A.R. Wellburn, The spectral determination of chlorophylls a and b, as well as total carotenoids, using various solvents with spectrophotometers of different resolution, J. Plant Physiol 144 (1994) 307-313.

[40] F.A.M. Wellburn, A.R. Wellburn, Atmospheric ozone affects carbohydrate allocation and winter hardiness of Pinus halepensis (Mill.), J. Exp. Bot 274 (1994) 607-614. 